\title{
СУЧАСНИЙ СТАН КОНТРОЛЮ В СФЕРІ БАНКІВСЬКОЇ ДІЯЛЬНОСТІ: ПРОБЛЕМИ ТА ШЛЯХИ ВДОСКОНАЛЕННЯ
}

\author{
CURRENT STATE OF CONTROL IN THE FIELD OF BANKING: \\ PROBLEMS AND WAYS OF IMPROVEMENT
}

\author{
А. В. Наконечна \\ адвокат, Головний спеціаліст ДППР АТ КБ “ПриватБанк”, \\ аспірант кафедри адміністративного та митного права, \\ Університет митної справи та фінансів
}

\author{
Alyona Nakonechna \\ Lawyer, Chief Specialist of DCCJ JSC CB «PrivatBank» \\ Postgraduate student of the Department of Administrative Tactical Law \\ University of Customs and Finance
}

У статті розглянуто сучасний стан контролю у сфрері банківської діяльності в Україні. Доведено, що його правова база в загальних рисах відповідає європейським стандартам і вдосконалюється з урахуванням вимог Базельського комітету за сприяння міжнародних організацій. Проблеми банківського контролю в Україні лежать в площині недостатнього розроблення нормативних документів і практичної реалізації їхніх положень. В статті розглянуто такі види контролю як банківський нагляд, внутрішній банківський контроль та незалежний аудит. Запропоновано застосування в Украӥні моделі банківського нагляду, яка передбачає його здійснення Національним банком України спільно з іншими контролюючими органами. Обгрунтовано необхідність подальшого вдосконалення систем діагностики фрінансового стану банку, контролю за наявністю та ефективністю систем управління ризиками, методики обчислення значень обов'язкових економічних нормативів та процедур банківського нагляду, заходів щодо протидії відмивання доходів, отриманих злочинним шляхом, розкриття інфрормації у фрінансовій звітності. Ключові слова: банківська система, банківський контроль, банківський нагляд, внутрішній аудит, зовнішній aydum.

В статье рассмотрено современное состояние контроля в сфрере банковской деятельности в Украине. Доказано, что его правовая база в общих чертах соответствует европейским стандартам и совершенствуется с учетом требований Базельского комитета при содействии международных организаций. Проблемы банковского контроля в Украине лежат в плоскости недостаточной разработки нормативных документов и практической реализации их положений. В статье рассмотрены такие виды контроля как банковский надзор, внутренний банковский контроль и независимый аудит. Предложено применение в Украине модели банковского надзора, которая предусматривает его осуществление Национальным банком Украины совместно с другими контролирующими органами. Обоснована необходимость дальнейшего совершенствования систем диагностики финансового состояния банка, контроля над наличием и эфффективностью систем управления рисками, методики вычисления значений обязательных экономических нормативов и процедур банковского надзора, мер по противодействию отмыванию доходов, полученных преступным путем, раскрытия инфрормации в финансовой отчетности.. Ключевые слова: банковская система, банковский контроль, банковский надзор, внутренний аудит, внешний аудит.

The article deals with the current state of control in the field of banking in Ukraine. It has been proven that its legal framework generally complies with European standards and is being improved taking into account the requirements of the Basel Committee with the assistance of international organizations. The problems of banking control in Ukraine lie in the plane of insufficient development of regulatory documents and the practical implementation of their provisions. The article discusses such types of control as banking supervision, internal banking control and independent audit. The application of the banking supervision model in Ukraine is proposed, which provides for its implementation by the National Bank of Ukraine in conjunction with other supervisory authorities. The necessity of further improvement of the systems for diagnosing the financial condition of the bank, control over the availability and efficiency of risk management systems, methods for calculating the values of mandatory economic standards and banking supervision procedures, measures to combat money laundering, disclosure of information in financial statements is substantiated. Ukraine has introduced a mixed form of banking control, which provides for the concentration of state control functions within the Central Bank in close cooperation with internal and external audit bodies. Borrowing international experience of control in the field of banking and its implementation at the national level. Development of a number of legislative acts that will coordinate the vectors of interaction between the bodies 
that exercise control in the field of banking. The problem of qualification of bank employees remains urgent, which is that the criteria for qualification of members of the executive body of the bank do not meet modern requirements.. Key words: banking system, banking control, banking supervision, internal audit, external audit.

Постановка проблеми у загальному вигляді та її зв'язок із важливими науковими та практичними завданнями. Банківський нагляд та банківський контроль, що здійснюються Національним банком України (далі - НБУ), є важливими компонентами підтримання стабільності банківської системи і забезпечення ефективного розвитку ринкових відносин.

Адже банки виконують на фрінансовому ринку специфічні фрункції, які мають не тільки фрінансовий, але й певний соціально значущий зміст. Через це проблеми, що виникають у банківській системі та в діяльності окремого банку, миттєво знаходять своє віддзеркалення в економіці та суспільстві, багато з них мають довгострокові й часто непередбачувані наслідки, призводять до структурних та інституційних диспропорцій в економіці, загострення фрінансових криз.

Аналіз останніх досліджень і публікацій. Питаннями фрінансового контролю займалися як зарубіжні так і вітчизняні вченіадміністративісти. Серед українських вчених можна відмітити дослі-дження Б. П. Адамика, О. І. Кірєєва, В. Л. Кротюка, А. М. Мороза, С. В. Моче-рного, А. А. Пересади, А. П. Яценюка, 3. М. Васильченко та ін. Однак ця про-блематика залишається відкритою та потребує детального вивчення.

Виділення невирішених раніше частин загальної проблеми, котрим присвячується означена стаття. Запозичення міжнародного досвіду контролю в сфрері банківської діяльності та впровадження його на національному рівні. Розробка низки законодав-чих актів, які здійснюватимуть координацію векторів взаємодії між органа-ми, які здійснюють контроль в сфрері банківської діяльності. Суть проблеми полягає у відсутності послідовності та чіткості правовідносин між різними органами влади, організаціями, установами тощо.

Формулювання цілей статті (постановка завдання). Стаття націлена на обґрунтування моделі, узагальнення принципів та викладення основних напрямів удосконалення контролю у сфрері банківської діяльності.

Виклад основного матеріалу дослідження. Враховуючи кризові тенденції на світових фрінансових ринках актуальності набуває питання формування надійної та ефективної банківської системи як в теоретичному, так і в практичному плані.

Оскільки, недосконале регулювання діяльності фрінансових посередників призвело до негативних подій в економіці світових країн. Саме тому світові організації розпочали пошук напря- мів підвищення ефективності системи регулювання та нагляду.

Концепція банківського нагляду в кожній країні має свою специфіку, пов'язану як з історичним розвитком, так і зі структурою влади та банківської системи.

Діюча нині банківська система України має дворівневу структуру, яка включає, з одного боку, Національний банк України (центральний банк) як головний банківський інститут, з іншого - мережу комерційних банків, які за умови нормальної конкуренції покликані задовольняти потреби населення і народного господарства країни у банківських послугах, створювати умови для стабілізації та поступового піднесення національної економіки.

Діяльність банків має двоїстий характер, оскільки вони виступають не тільки як комерційні підприємства, але в сукупності - як важливий соціальний інститут. Як комерційні підприємства вони зацікавлені в отриманні максимального прибутку, як соціальний інститут - разом з центральним банком $є$ фрундаментом і найважливішим елементом інфраструктури ринкової економіки. Разом з іншими елементами цієї інфраструктури банки покликані забезпечити умови для нормальної життєдіяльності держави та підвищення рівня життя населення. Тому забезпечення стійкого функціонування банків та виконання ними важливих суспільних функцій вимагає постійного нагляду та контролю за їх діяльністю.

На жаль, довіра населення до банків України поки що залишається, якщо вже не низькою, то явно недостатньою. Першого удару по ній завдала невиплата Ощадбанком України вкладів населення в установах Ощадного банку колишнього СРСР, зобов'язання якого взяв на себе уряд України. Далі недовіру підсилювали щорічні банкрутства багатьох банків, які не повернули вкладникам значні суми. Тільки в 2001 році збанкрутували такі великі банки як "Україна" та "Слов'янський”, які не спроможні були одразу повернути вкладникам сотні мільйонів гривень. Тому для того, щоб відновити довіру населення до банків, потрібно створити ефективну систему фрінансового контролю банківської діяльності. Така система покликана забезпечити прозорість діяльності банків та попередити їх банкрутства.

Організація ефективного фрінансового контролю за діяльністю банків є досить складним процесом та вимагає вирішення багатьох завдань та проблем.

Надзвичайно важливою є проблема забезпечення надійності, прозорості, профресійності, 
та створення повноцінної законодавчої бази для проведення

контролю у сфері банківської діяльності.

Також потребує вирішення проблема вдосконалення організації та поєднання всіх видів фінансового контролю. Розв'язання даної проблеми має важливе значення для успішного розвитку банківської системи України, і як показав аналіз наукових публікацій та методичних матеріалів, поки що вона є недостатньо розробленою в теоретичному і практичному плані.

Головною метою даного дослідження $є$ розкриття сутності системи контролю у сфері банківської діяльності в Україні, виявлення її переваг та розробка пропозицій щодо усунення недоліків.

Перш за все, треба визначити, що являє собою система фінансового контролю банківської діяльності. Це система контролю та активних впорядкованих дій Національного Банку України та інших спеціальних служб, спрямованих на забезпечення дотримання банками законодавства України і положень внутрішніх та зовнішніх нормативних актів при здійсненні операцій банку, достовірності та повноти інформації для забезпечення стабільності банківської системи та захисту інтересів вкладників і кредиторів банку.

В Україні система фінансового контролю банківської діяльності включає такі види контролю: державний, внутрішній банківський контроль, незалежний аудит.

Державний фрінансовий контроль в Україні здійснюється у формі банківського нагляду. Для того, щоб банківський нагляд став ефективним видом контролю потрібно дотримуватись таких принципів:

1. Обов'язковість та універсальність.

2. Законодавче закріплення за Національним банком (та/або іншими органами) наглядових функцій з наданням йому права видавати відповідні нормативні акти, які є обов'язковими до виконання всіма банками.

3. Єдність вимог наглядових органів.

4. Єдність кількісного та якісного контролю.

5. Поєднання дистанційного (документарного) і “контактного” (перевірки на місцях) методів нагляду.

6. Профресіоналізм контролю.

7. Адекватність контролю.

8. Конструктивний характер нагляду.

9. Консолідований характер нагляду.

10. Поєднання всіх видів контролю (державного, суспільного, внутрішнього, незалежного).

11. Достовірність звітності і повна відповідальність за її якість та конфіденційність.

12. Забезпечення прозорості функціонування банківської системи.

Як показує світовий досвід, практика нагляду, який по суті є контролем, за діяльністю банків у різних країнах відрізняється не тільки різноманітністю форм його організації, а й органами, які його проводять.

Органами нагляду можуть бути:

- структурний підрозділ (управління, департамент) центрального банку (Нідерланди, Греція, Іспанія, Нова Зеландія);

- незалежний контрольний орган, комісія, агентство або декілька паралельних органів (Австралія, Велика Британія, США, Швеція);

- відділ при міністерстві, зазвичай, при міністерстві фрінансів (Австрія, Канада, Норвегія, Португалія).

У деяких країнах (Німеччина, Франція, Італія, Швейцарія) існує змішана система банківського і фінансового нагляду, у рамках якої наглядові функції центральний банк поділяє з іншими державними органами.

Діяльність наглядових органів регламентується системою законів та інших правових актів, що враховують особливості історичного та економічного розвитку держави.

Отже, суть організаційної форми нагляду за діяльністю банків в кожній країні має свою специфіку, пов'язану як з історичним розвитком, так і зі структурою влади та банківської системи, зокрема, з кількістю, видами, розгалуженістю банківських установ та іншими факторами. Тому установа, яка здійснює контроль в сфері банківської діяльності, на нашу думку, повинна мати всі необхідні повноваження для ефективного виконання поставлених перед нею завдань, самостійно приймати рішення, бути незалежною від політики, брати участь в управлінні грошовокредитною політикою. Усі ці повноваження, звичайно, мають бути закріплені законодавчо.

В Україні функцію банківського регулювання та нагляду згідно із Законами "Про банки і банківську діяльність" та "Про Національний банк України” здійснює Національний банк України.

Система банківського нагляду скоординована вертикально і функціонує як

єдиний механізм у складі центрального апарату та регіональних управлінь НБУ.

На основі аналізу Положення НБУ «Про застосування Національним банком

України заходів впливу до комерційних банків за порушення банківського законодавства» та закону України «Про банки та банківську діяльність» можна виділити такі фрорми банківського нагляду в Україні:

- реєстрація та ліцензування банку;

- здійснення безвиїзного моніторингу банку;

- здійснення комплексного чи тематичного виїзного інспектування банку;

- визначення рейтингової оцінки комерційних банків;

- застосування заходів впливу до банків, що 
порушили чинне законодавство.

Розглянемо зазначені етапи банківського нагляду докладніше.

Нагляд починається із появою банку. Створення нової банківської установи чи її фрілії починається з реєстрації. У законодавстві майже всіх країн процес реєстрації банків набагато складніший за реєстрацію будь-якого іншого суб'єкта підприємницької діяльності і вимагає задоволення низки передбачених законом вимог. Це стосується і законодавства України, де механізм створення і реєстрації банків регулюється законами "Про банки і банківську діяльність", “Про Національний банк України”, а також Положенням про порядок створення і державної реєстрації банків, відкриття їх фрілій, представництв, відділень. Основними в пакеті документів, необхідних для державної реєстрації, $є$ установчі документи, на яких ґрунтуватиметься уся подальша діяльність банку. До них належать: рішення про створення банку (протокол установчих зборів), установчий договір та статут банку.

Після реєстрації банку НБУ визначає порядок видачі банкам та банківським корпораціям ліцензій. Основні умови отримання банківської ліцензії закріплені в ст. 19 Закону України "Про банки і банківську діяльність".

У відповідність із Положенням про порядок видачі банкам банківських ліцензій на час звернення банку з клопотанням про видачу банківської ліцензії повинен бути повністю сплачений його зареєстрований підписний капітал у розмірі, передбаченому чинним законодавством.

Жодна особа не має права залучати вклади та інші кошти, що підлягають поверненню, надавати кредити, а також вести рахунки без банківської ліцензії. Встановлено чіткі критерії надання банківської ліцензії, на підставі якої банки можуть приймати вклади (депозити) від юридичних і фрізичних осіб, відкривати рахунки клієнтів і банків-кореспондентів та розміщувати залучені кошти від свого імені. Ці операції належать виключно до банківських операцій, здійснювати які в сукупності дозволяється тільки юридичним особам, які мають банківську ліцензію. На нашу думку, вдосконалення нагляду на цьому етапі може відбуватись за такими напрямами. По-перше, необхідно вдосконалити нагляд за учасниками (засновниками) та акціонерами банків, змінити підходи до перевірки джерел походження коштів при реєстрації банку з метою визначення його реальних власників, надати НБУ повноваження щодо відмови банку у реєстрації у разі неможливості встановлення реальних власників або акціонерів банку, тобто при відсутності прозорої структури власності.

Необхідно здійснювати постійний моніторинг за фрінансовим станом юридичних осіб - влас- ників великих пакетів акцій банків з метою усунення можливостей обходу нормативно встановлених обмежень максимального ризику при кредитуванні засновників та інсайдерів шляхом створення афрілійованих структур і структур, що ними контролюються. Також вважаємо, що один із засновників має виступити гарантом надання фрінансової підтримки у разі виникнення у банку фрінансових складностей.

Інститут гаранта повинен діяти впродовж всієї діяльності банку. Цим забезпечуватимуться мінімальна відповідальність за діяльність банку та гарантія підтримки фрінансової стійкості на початку його фрункціонування.

По-друге, необхідно вдосконалити нагляд за керівниками банків (філій). Поряд з вимогами щодо профресійної придатності та бездоганної ділової репутації керівників банків треба враховувати і їхні моральні якості, як це робиться у західних країнах.

НБУ доцільно надати право на немотивовану відмову при погодженні кандидатур у випадках, коли $є$ інформація про сумнівну комерційну репутацію кандидата або про його зв'язки з кримінальними структурами. Слід встановити заборону на поєднання посад керівників та головних бухгалтерів банку однією фрізичною особою та в різних банках. Ще одним напрямом підвищення відповідальності керівників банків могло б бути підвищення їхньої матеріальної відповідальності за завдані збитки. В деяких західних країнах така відповідальність поширюється на все майно керівника (менеджера), навіть на майно усіх членів його сім'ї.

Безвиїзний моніторинг банку - це наступний етап контролю, метою якого $є$ забезпечення перевірки дотримання банками встановлених вимог, розумне (з оптимальним ризиком) ведення ними власних справ.

Для забезпечення фрінансової надійності комерційних банків НБУ, відповідно до визначеного ним порядку, встановлює для них обов'язкові економічні нормативи. Функція нормативу - визначення ступеню захищеності від певного виду ризику.

НБУ установив такі економічні нормативи, що $€$ обов'язковими до виконання всіма банками: нормативи капіталу - мінімальний розмір регулятивного капіталу (H1), адекватність регулятивного капіталу (H2), адекватність основного капіталу (H3); нормативи ліквідності - миттєва ліквідність (H4), поточна ліквідність (H5), короткострокова ліквідність (H6); нормативи кредитного ризику максимальний розмір кредитного ризику на одного контрагента (H7), великий кредитний ризик (H8), максимальний розмір кредитів, гарантій та поручительств, наданих одному інсайдеру (Н9), максимальний сукупний розмір кредитів, 
гарантій та поручительств, наданих інсайдерам (Н10); нормативи інвестування - інвестування в цінні папери окремо за кожною установою (H11), загальна сума інвестування (H12); норматив ризику загальної відкритої (довгої/короткої) валютної позиції банку (Н13).

Безвиїзний нагляд використовується як система раннього застереження, що дає змогу наглядовим органам ухвалювати рішення про застосування щодо банків коригувальних заходів ще до загострення ситуації або до проведення інспекційної перевірки. Цей нагляд ґрунтується на аналізі звітності, що подається НБУ на регулярній основі (щоденно, щомісячно та квартально). Дані звітності аналізуються і зводяться у статистичні звіти, за якими розраховуються різні стандартні показники.

Такі звіти дають змогу виявляти, чи дотримуються банками економічні нормативи, досліджувати тенденції в діяльності банків за певний період, проводити порівняльний аналіз за групами банків.

Проблемою на цьому етапі банківського нагляду $є$ достовірність звітності. Це проблема "номер один" у забезпеченні ефективності безвиїзного нагляду, оскільки деякі банки свідомо припускаються викривлення фінансових результатів діяльності, заниження оподатковуваної бази і даних для розрахунку розміру обов'язкових резервів. Це означає, що з виникненням серйозних проблем знижується ймовірність отримання від банку адекватної й повної інформації про ситуацію, що склалася в ньому.

Наступний етап виїзне інспектування, тобто перевірка діяльності комерційного банку з виїздом на місце на підставі вивчення та аналізу первинної документації, зіставлення її з даними звітності, яка подається до Національного банку України у рамках нагляду.

Основними завданнями таких перевірок $€$ :

- визначення на місці реального фрінансового стану банку;

- оцінка рівня основних банківських ризиків;

- наявність ефективної системи управління банком;

- перевірка відповідності здійснюваних операцій банківській ліцензії, банківському законодавству та нормативним актам НБУ;

- перевірка дотримання банком обов'язкових економічних нормативів, формування резервів під активні операції та інших пруденційних норм діяльності;

- перевірка достовірності інформації, поданої у щоденних звітах до НБУ в

межах нагляду;

- перевірка стану внутрішнього контролю у банку;

- оцінка якості аудиторського висновку та ін.
Таким чином, загальна мета інспектування полягає в тому, щоб НБУ отримав інформацію про реальний стан комерційного банку. Проте, ця загальна мета, на наш погляд, включає дві конкретні мети. По-перше, в процесі інспектування слід визначити стан банку та перспективи його розвитку; по-друге, необхідно зібрати та проаналізувати інформацію, яка дасть змогу виявити його вплив на інші банки.

Сьогодні на практиці інспектування обмежується переважно вивченням

комерційного банку як такого, а зв'язки між конкретними банками не аналізуються, що в майбутньому може призвести до значних проблем.

Відповідно до результатів комплексного інспектування визначаються та затверджуються рейтингові оцінки за компонентами системи CAMEL і комплексна рейтингова оцінка.

Другий вид контролю за банківською діяльністю це внутрішній контроль. Внутрішній банківський контроль - це сукупність процедур, які забезпечують дотримання положень внутрішніх і зовнішніх нормативних актів при здійсненні операцій банку та достовірність і повноту інформації. Система внутрішнього банківського контролю складається з двох підрозділів: бухгалтерський контроль; внутрішній аудит.

Бухгалтерський контроль - це сукупність процедур, що дають змогу забезпечити збереження активів банку та достовірність звітності, що складається службою бухгалтерського обліку на основі даних, отриманих від операційних підрозділів.

Головною ж метою системи внутрішнього аудиту є оцінка достатності нагляду за ризиком. Створення служби внутрішнього аудиту, її основні функції, межі відповідальності закріплено в Законі України «Про банки та банківську діяльність».

В організації та функціонуванні внутрішнього аудиту на сучасному етапі, на наш погляд, існує ряд проблемних питань. Серед яких на першому місці питання взаємодії внутрішніх аудиторів з працівниками банківського нагляду. Практично працівники банківського нагляду не мають можливості використовувати у своїй роботі звіти та рекомендації служби внутрішнього аудиту банку. Звіти, які вони отримують, містять інформацію лише про стан внутрішнього аудиту в банку, а саме: кількість здійснених перевірок та періодичність їх проведення; наявність внутрішніх документів, якими регулюється діяльність банку; наявність системи оцінки ризиків, які бере на себе банк, та інше.

У більшості банків робота внутрішнього аудиту спрямована на виявлення та

усунення помилок бухгалтерського обліку, контролю за ризиками, причому без 
застосування системного підходу. Зокрема, проведення перевірок правильності ведення бухгалтерського обліку перешкоджає якісному здійсненню внутрішнім аудитом таких необхідних функцій, як перевірка обґрунтованості оцінки відповідальними працівниками кредитного та інших ризиків, аналіз достатності контрольних заходів стосовно тих чи інших операцій.

Слід зазначити, що внутрішній аудит може сприяти виконанню банком завдань, досягненню ним певного рівня прибутку, дотриманню законодавства, а також зниженню ризику непередбачених збитків або запобіганню тому, щоб репутації банку було завдано шкоди.

Тому важливим напрямом вдосконалення внутрішнього аудиту в банках, на

нашу думку, є підвищення статусу цієї служби та ролі в корпоративному управлінні.

Ще одним важливим видом контролю банківської діяльності $є$ зовнішній аудит.

Фінансові звіти, які банки подають до НБУ, щорічно мають бути перевірені зовнішнім аудитором, який отримує сертифрікат НБУ на аудиторську перевірку банківських установ. Вимоги щодо зовнішнього аудиту викладено у ст. 69 Закону України “Про банки і банківську діяльність”, а також у постанові Правління НБУ від 09.02.1999 р. № 53 “Про заходи з подальшого розвитку банківського аудиту".

Отже, банк наймає зовнішніх аудиторів переважно для перевірки річних звітів банку, але ці аудитори здебільшого виконують і певну частку тестування системи внутрішнього контролю залежно від розмірів та обсягів охоплення банку внутрішнім аудитом та від рівня системи внутрішнього контролю.

Заслуговує на увагу досвід співпраці зовнішніх аудиторів з наглядовими органами у деяких зарубіжних країнах. Так, у Нідерландах між банком, зовнішнім аудитором та центральним банком країни укладається тристороння угода про надання інформації наглядовому органу. До такої інформації належать: аудиторський висновок, інформація керівництву банку (опис фрактів, які були виявлені аудитором під час перевірки річного звіту, з рекомендаціями щодо поліпшення ситуації), а також "спонтанна" інфрормація органу нагляду, якщо позитивний висновок опиниться під загрозою або якщо є інша "небезпека".

У Великобританії раз на рік проводяться тристоронні зустрічі за участю представників органу банківського нагляду, банків та їхніх аудиторів, на яких обговорюються актуальні питання обов'язкового аудиту. Ці зустрічі проводяться зазвичай тоді, коли наглядовий орган вже отримав звіти про бухгалтерські та інші записи систем внутрішнього контролю і звіти з коментарями до них керівництва банку.
Крім того, наглядовий орган може з власної ініціативи акцентувати увагу банків, аудиторів на певних фактах, якщо ознайомлення з ними може вплинути на зміст їхніх висновків або на хід ведення аудиту.

Питання про запровадження таких зустрічей за участю НБУ, банків та зовнішніх аудиторів в Україні порушувалося кілька років тому, однак не дістало належної підтримки. На нашу думку, варто уважно розглянути механізм ділового співробітництва офріційних і незалежних банківських аудиторів з метою його запровадження у банківському секторі економіки України.

Для поліпшення якості аудиторських звітів слід розробити нові і внести зміни до чинних нормативно-правових актів НБУ щодо ведення реєстру аудиторських фрірм, яким надано право проводити аудит банків. Цю роботу вже розпочинають фрахівці НБУ. Потрібно також ініціювати внесення змін до Законів України "Про аудиторську діяльність" та "Про банки і банківську діяльність” щодо визначення процедури розробки національних стандартів зовнішнього аудиту на основі міжнародних стандартів.

Нагальною лишається проблема кваліфікації працівників банківських службовців, яка полягає в тому, що критерії кваліфрікації членів виконавчого органу банку не відповідають вимогам сучасності. Вимоги, що висуваються (наявність вищої економічної або юридичної освіти, кілька років роботи на керівних посадах та рекомендація особи, що вже була погоджена з НБУ) далеко не гарантують компетенцію потенційного керівника банківської установи. Адже управління сучасним банком вимагає певних знань у галузі макроекономіки, юриспруденції, технології банківських операцій, управління ризиками. Обов'язковою умовою добору кадрів має стати необхідність періодичного підтвердження кваліфікації. Відсутність подібного заходу вже на сьогодні призвела до суттєвого розриву між середнім кваліфрікаційним рівнем керівників середньої ланки та топ-менеджерами банків. Як результат, спостерігається неоптимальне використання банківською системою свого інтелектуального потенціалу.

Висновки з цього дослідження. Підводячи підсумок, зазначимо, що в Україні запроваджено змішану форму банківського контролю, яка передбачає зосередження функцій державного контролю в рамках Центрального банку у тісній взаємодії з органами внутрішнього та зовнішнього аудиту. 


\section{БІБЛІОГРАФІЧНИЙ СПИСОК:}

1. Банковский контроль и аудит: Учеб. gособие; Под общей редакцией. Н.В. Фадейкиной.М.: Финансы и статистика, 2002. 496 с.

2. Васильченко 3.М. Комерційні банки: реструктуризація та реорганізація: Монографрія. К.: Кондор, 2004. $528 \mathrm{c}$.

3. Грушко В.І., Лаптєв С.М., Лобань О.С., Раєвський К.Є. Банківський нагляд : Навчальний посібник. К.: Центр навчальної літератури, 2004. 264с.

4. Міщенко В.І., Яценюк А.П., Коваленко В.В., Коренєва О.Г. Банківський нагляд: Навч. Посіб. К.: Знання, 2004. 406 c.

5. Никитина Т.В. Банковский менеджмент. СПб: Питер, 2002. 160 с.

\section{REFERENCES}

1. Fadeikina, N.V e.d. (2002). Bankovskiy control i audit [Banking control and audit]. Siberian Institute of Finance and Banking. Moskow: Finance and statistics. (in Russian).

2. Vasilchenko, Z.M. (2004) Comercijni banki: restrukturizacija i reorganizacija [Commercial banks: restructuring and reorganization]. Monograph. Kyiv: Condor. (in Ukrainian).

3. Grushko, V.I., Laptev, S.M., Loban, O.S., Raevskiy, K.Ye. (2004). Bankivskij nagljad [Banking supervision ]. Tutorial. Kyiv: Center for Naval Literature. (in Ukrainian).

4. Mishchenko, V.I., Yatsenyuk, A.P., Kovalenko, V.V., Koreneva, O.G. (2004). Bankivskij nagljad [Banking Supervision]. Textbook. Kyiv: Knowledge. (in Ukrainian).

5. Nikitina, T.V. (2002). Bankovskij management [Banking management]. SPb: Peter. (in Russian). 